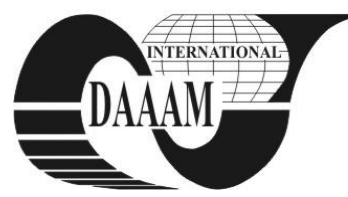

\title{
STRATEGIES TO INCREASE THE COMPETITIVENESS OF INDUSTRIAL PRODUCTS IN THE CONTEXT OF THE GLOBAL ECONOMIC CRISIS
}

\author{
POPESCU, D[oina] \& RADU, C[atalina]
}

\begin{abstract}
The paper presents the importance of implementing the appropriate strategies depending on the exogenous and / or endogenous factors that characterize the changes in the business environment. Thus, by using innovation strategies (e.g. an unmet need on the market) and by shifting from fragmentary execution to overall strategy companies can increase their competitiveness in times of crisis. The paper also presents the results of a survey on the strategies used by textile \& clothing companies in Romania, a sector which is representative in terms of the entrepreneurial strategies used.
\end{abstract}

Key words: competitiveness, full-business, innovation, market gap, economic crisis

\section{INTRODUCTION}

The global economic and financial crisis affecting all world economies has forced various actors to work together to ensure coherence and synergies between their specific roles in the restructuring and recovery process after the crisis.

The enormous social and economic changes that occurred in Europe in recent years have had a considerable impact on the business environment of companies, especially of small and medium enterprises (SMEs). In order to cope with these changes and to increase their competitiveness, companies must constantly adapt and learn to innovate. Thus, the entrepreneur's vision (the change initiator), translated into the terms and objectives of the strategy is to implement a culture of innovation, where the innovation process becomes part of the daily routine. Focusing on innovation implies changes in the held portfolio. Therefore, a more in-depth categorization may benefit more efficiently from the attention and the resources allocated in order to create an innovative culture. The final goal is to create a consumer-oriented social system inside the company, which should have the capacity to maximize the personnel's skills and creativity.

An appropriate strategic position for any firm depends on two factors: (1) its resources and capabilities and (2) the condition of its industry environment. A firm with strong innovative capabilities will generally take advantage of its ability to make product improvements, whether incremental or radical, enabling the company to offer newer and unique products targeting specific customers.

Innovation can be fostered by using the employees' skills and taking into consideration their interests, as well as by establishing partnerships with other companies.

In order to keep in contact with the external environment, companies have to create external development groups, whose role is to hold meetings with individuals, groups, research labs, collaborators and even market competitors and to gather their suggestions regarding new technologies, prototypes or connections with the consumer base.

In addition, companies have to collect ideas from several areas. In the past century, innovation was created in the developed countries and exported to the emerging markets. When new technologies were conceived in Japan, Germany or USA, they were exported primarily in the region, beginning with the more developed countries. Nowadays, over $40 \%$ of the innovation originates from outside the USA. India, China, South America and even Africa have become part of the social system.

More advanced firms are currently struggling to switch from ensuring consumer satisfaction to ensuring consumer loyalty (continued long-term relationship between the firm's offer and the consumer, the offer that consumers trust) and consumer enthusiasm (surprising consumers by anticipating or even creating needs and desires which are not expressed unmet needs). In this final stage of consumer engagement, the consumer develops a powerful emotional connection with the supply company which becomes an important part of his life. Enthusing the consumer is considered to be the new frontier that allows for the differentiation of supply over the competition.

An unmet consumer need on the market can be of strategic importance, in that it can represent an opportunity for those companies trying to gain market share, and a threat for the ones which are seeking to maintain their position on the market.

\section{PROGRAMS AIMING TO INCREASE THE COMPETITIVENESS OF INDUSTRIAL PRODUCTS}

In Romania there are some projects funded by the Ministry of Economy, Trade and Business Environment within the program aiming to increase the competitiveness of industrial products OHSAS 18001/1999 (health system management and safety) and SA 8000 (Social Responsibility). These programs bring together the social partners and the Romanian government to cooperate in the field of competitiveness. The main objective of this dialogue is the concept of decent work as a competitive factor.

\begin{tabular}{|c|c|c|}
\hline Year & $\begin{array}{c}\text { Number of funded } \\
\text { projects }\end{array}$ & Value -EUR- \\
\hline 2005 & 76 & 830,472 \\
\hline 2006 & 84 & $1,457,635$ \\
\hline 2007 & 54 & $1,502,567$ \\
\hline 2008 & 43 & 812,250 \\
\hline 2009 & 10 & 123,317 \\
\hline 2010 & 4 & 96,976 \\
$\left(1^{\text {st }}\right.$ sem. $)$ & 271 & $4,823,217$ \\
\hline $\begin{array}{c}\text { Total } \\
\left(1^{\text {st }} \text { sem. }\right)\end{array}$ & & \\
\hline
\end{tabular}

Tab. 1.Funded projects OHSAS 18001/1999 and SA 8000(IBD)

However, during the crisis there was a decrease in the number of companies which applied for public funds in order to implement occupational standards. 


\section{STRATEGIES USED BY TEXTILE\&CLOTHING COMPANIES IN ROMANIA}

There were several reasons which have led us to select the textile \& clothing sector in Romanian for a case study. On the one hand, this field of activity is the leading branch within the light industry in Romania and it boasts a long tradition in the export of a diversified product mix. On the other hand, it concentrates the largest number of SMEs in the industry and it is representative in terms of the business strategies used.

The evolution of the textile \& clothing destination has seen a significant change with the transition to the market economy (Fig. 1). In 2010, approximately $90 \%$ of Romania's total exports were to EU countries, so any change that occurred in this market was felt by the local industry and trade of textiles and clothing.
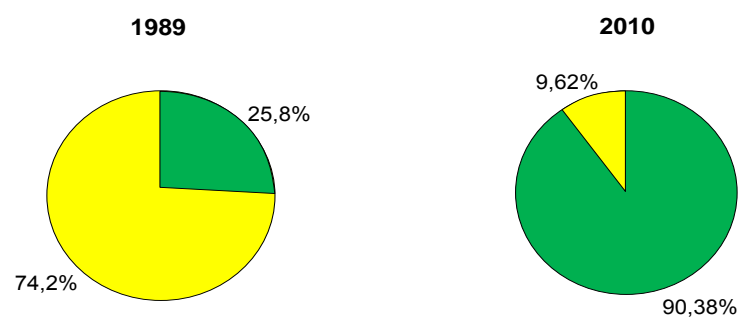

$\square$ Export

$\square$ Import

$\square$ Export

$\square$ Import

Fig. 1. Evolution of product destination

In order to identify the strategies used by the textile \& clothing companies in Romania to ensure their survival during the global economic crisis a survey based on a questionnaire was carried out. The study included a number of 102 Romanian textile \& clothing firms from all over the country (textile companies, ladies garment companies, men's garment companies). Another objective of the research was to identify which strategies enhance competitiveness and how they can be achieved.

The survey has revealed the following:

- only 23 company managers out of 102 have developed and implemented a strategy to reduce lohn (outward processing) production. The 23 managers can manufacture their own brands simultaneously with processing in the lohn system. Out of these 23 companies, only three export their production under their own brand. One has developed a niche market (clothing for a certain segment of sports, namely paragliding and hang gliding) and another one is producing organic clothing. The third company exports men's shirts under its own brand and it has managed to retain its brand identity since 1997 .

The remaining 20 companies with their own brand are targeting the domestic market. The managers of the other 79 companies said that lohn processing was the only viable solution. In support of this claim, they identified the following causes for which they cannot produce their own brand and they cannot manufacture full products: lack of quality raw materials; impossibility of taking bank credit for investment; impossibility of penetrating foreign markets; shortage of skilled labor (labor migration).

- managers of the three companies which export their own brand (full business) purchase their raw materials from abroad and accessories from importers and/or Romanian producers. The company which exports sport articles uses "smart" textiles, materials with aerodynamic properties and the organic clothing company uses organic cotton. Thus, these firms apply the innovation strategy in order to gain and protect their market share.

- only two of the three companies with full exports have accessed public funds for the implementation of occupational standards within the program to increase industrial competitiveness (OHSAS18001/1999 and SA 8000), as a response to one of the trends imposed by the economic crisis related to clothing production and trade. (i.e. the ethical fashion concept associated with fair trade, recycling and organic textures - fair trade apparel).

The manager of this company considers that its products are targeting consumers who believe in a world without artificial colors, with decent working conditions for employees and not only. Thus, the manager believes that the success of the products consists in that they meet the requirements of consumers who are interested in the moral aspect of clothing production, but also of those related to the particular functionality and appearance.

This strategy represents one way to react with a view to identifying unmet needs on the market.

So, in order to increase the competitiveness of their products, very few Romanian companies produce under their own brand, using either smart textiles or organic materials or producing ethical fashion. Thus, they operate in niche markets, using the innovation strategy and the identification of unmet needs on the market.

The companies with full business (supported by lohn) as their main way for increasing competitiveness have invested in the imposition of a brand. This implies operating and managing all five functions of the firm $(\mathrm{R} \& \mathrm{D}$, commercial - with three components, manufacturing, financial-accounting and HR). Two out of these three companies have accessed funds under the program to increase competitiveness.

\section{CONCLUSIONS}

During a global economic crisis with effects on consumption and production, most companies consider the lohn processing system as the only viable one for maintaining market share.

On the other hand, very few companies have managed to impose their own brands (as the main way for increasing competitiveness) and an even smaller number of companies manage to export their own brand using the innovation strategy and identifying the opportunities for the long-term success of the company. For these reasons it is necessary to create an innovative culture among the firms in the Romanian clothing sector, as well to highlight the necessity of creating own brands in order to increase competitiveness.

\section{ACKNOWLEDGEMENTS}

This work was co-financed by the European Social Fund through the Sectoral Operational Programme Human Resources Development 2007-2013, project no. POSDRU/1.5/S/59184 "Performance and excellence in postdoctoral research in Romanian economics science domain".

\section{REFERENCES}

Aaker, D. (2007) Strategic Market Management, John Wiley \& Sons Inc., New York

Anton, V. (2006) Marketing interorganizaţional, Ed. Expert, Bucureşti

Carpenter, M., A., Sanders, Wn., G. (2009) Strategic Management, Pearson International Edition, N.J.

Kotler, Ph., Keller, K., L., (2005),"Marketing Management", Pearson Prentice Hall, N.J.

Popescu, D. Bâgu, C., Popa, I. \& Hâncu, D. (2009). Posibilităti de realizare a exporturilor integrale ale firmelor de confecţii îmbrăcăminte din România în contextul crizei economice mondiale, Rev. Industria Textilă no. 6, Editura CERTEX, pp. 334-340

Popescu, D. (2009), Asigurarea avantajului competitiv în firmele de confecţii îmbrăcăminte din România, Rev. Industria Textilă no. 3, Editura CERTEX, pp. 153-158

Robbins, S. P., Coulter, M. (2003) Management International Edition, Seventh edition, Upper Saddle River, N.J., Prentice Hall 